\title{
ADMINISTRATIVE REFORMS OF THE EUROPEAN SOCIAL PROTECTION SYSTEMS: TRENDS AND CHALLENGES
}

\begin{abstract}
Initiatives for social reforms are part of the governmental agendas of almost all European countries. The introduction of support for the households by guaranteeing minimum incomes, activation of the social assistance beneficiaries, as well as delivery of integrated services in the local community are the main challenges of the contemporary social protection systems.

Reflecting the significance of institutions (establishment, organization and administrative capacity) as a key condition for achievement of socially-accepted goals, European countries, in the last few decades, have been implementing administrative reforms of social protection systems. The countries are searching for improved institutional arrangements for maximization of policy effects directed towards social inclusion and reduction of social tensions in the societies. In most cases, countries introduce administrative modalities based on managerial doctrines of governing (new public management), while others experiment with a certain form of decentralization which usually includes initiatives for local provision of social services and, in certain cases, integration with employment services. Yet, although a part of the administrative reforms are being implemented with the same purpose, they lead to different institutional solutions as a result of the social context in which they are framed.

This article gives an overview of the trends in the development of the social protection systems of the European countries, which despite the efforts for convergence of social policies and the creation of a unified social model, continue to show diversity of legal and institutional solutions at the national level.
\end{abstract}

Keywords: SOCIAL PROTECTION, SOCIAL SERVICES, INSTITUTIONAL FRAMEWORK, ADMINISTRATIVE REFORMS

\section{Introduction}

The social protection systems of the European countries show differences in the field of regulation, organization, financing and monitoring of the measures directed towards protection of the socially vulnerable citizens. This situation is a result of influences of various factors related to historical, geographical, political and socio-economic characteristics of the countries. 
European countries engaged in institutional reforms can be divided in two groups: developed Western-European countries with stable systems of social security which had to respond to the new challenges and labour market changes, and the countries from the former communist block which performed a complete transformation of the social security system inspired by the social-political changes and emerged socio-economic problems ensuing the transitional processes. The recent global crisis and the consequences on the labour market imposed more challenges for the welfare countries, especially for the social protection and employment services. Most of these challenges are not new, since the post-industrial labour markets are subject to frequent structural changes caused by the technological development, demographic trends and globalization. The countries from Central and East Europe are facing a greater challenge considering the insufficient stabilization of the social protection systems and the newly adopted work methods and principles.

Although the external challenges are similar, the political responses of the European welfare states show significant variations. This is due to the different character and the nature of the need for changes on one side, and diversity regarding the actors and the institutions shaping the process of policy making in these countries on the other. Different factors affect the process of change: political establishment, election system, tradition for forming coalition government, strength of the opposition, level of decentralization, right to veto given to different actors or the political frame of the economic relations. Cross country variations in policy outcomes emerged as a result of different influence factors show why specific reforms with similar ideology and goals (for example the neo-liberal policy) did not achieve same results in each of them respectively (Scharle, 2014).

\section{Normative approach and organization of the social protection}

The European countries have different normative approach to the social protection system regulation. Part of them have systematic laws regulating all important social protection issues (content, organization, financing), and part of them have divided the legal regulations in certain number of legal acts. There are many examples of normative separation of certain segments in specific laws (certain social services) in the countries with systematic regulation of the social protection. The countries that have accepted the approach of fragmented regulation, mostly have one law regulating the social services (with special regulation of certain specific services), and one or more laws regulating the social benefits. The social protection of children and the family benefits are subject to special regulation. Moreover, there are special laws for social protection of older persons and persons with disability. 
The analysis shows that the approach of legal unification does not affect the structure of the social protection system. Namely, the deficit of an integral legal document and the regulation through several legal acts does not complicate the system, or certain aspects of the social protection. On the contrary, the special regulation enables easier reading of the legal texts which are not burdened with various general rules, thus becoming a more effective tool for realization of the citizens' rights. Also, the analysis has outlined that the normative regulation (one of more legal texts) does not affect the complexity of the institutional framework. The example of the Czech Republic demonstrates a relatively simple organizational structure for social benefits administration, although there is a lack of systematic social welfare law, compared to Croatia with a simpler normative framework, but a complex institutional setting and fragmented administration of the social benefits.

Various factors influence the organization of the social protection systems: the political system of the country, the devolution of state competences to the level of governance, administrative-territorial organization, tradition etc. All European countries have adopted the principle of a so-called "small state", according to which the ministries (the central authority) competent for the affairs in social protection have regulatory and oversight function. Diversity appears as a result of different areas covered by the ministries (social protection, social insurance, health, family and children protection), as well as in the number of ministries participating in the execution of the social protection. The federal countries have complicated organizational structure which includes division of the competencies between the central authority and the federal units, and mostly they have branched structure which includes many competent ministries (Austria, Germany, Switzerland, Belgium). The modality of the organization in the unitary states may vary from a plain one represented by one ministry (Greece, the Netherlands, Italy, Bulgaria, Slovenia, Poland, the Czech Republic) which in certain cases covers health issues (Finland, Estonia), to more complicated structures with more ministries engaged in the social protection system (Denmark, France, Croatia). In some countries two ministries are authorized for social protection affairs, one competent for employment and social security, while the other for social services and health protection (Sweden and Spain).

The division of responsibilities between the central and the local authority is conditioned by the general rules, primarily regarding the functionnal and fiscal decentralization of the competences. The central authority, in most cases, is competent for social benefit administration through establishment of an independent body with national competencies (Estonia). In the countries with powerful multi-tiered local self-government, the administration of the social benefits is under jurisdiction of the regional or municipal governments. The social services are mostly decentralized and the same are delivered by the local authorities. 


\section{Administrative reforms of the social protection systems}

Regardless of the differences in the social protection systems arrangement and organization, EU member states share certain trends in the reform Table below lists the initiatives for policies changes grouped by certain areas in the period of 2014-2015.

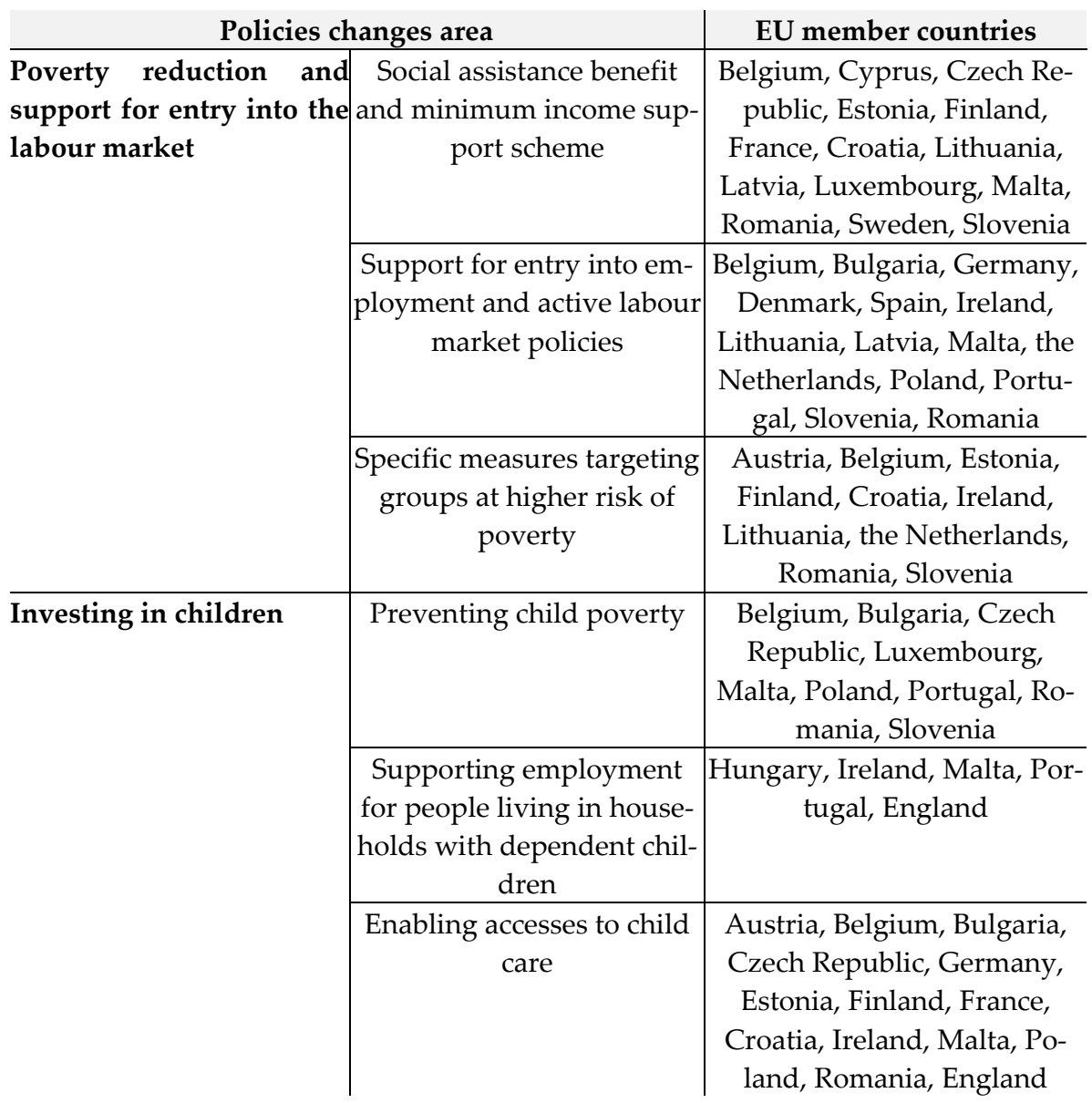

Source: Social Protection Committee, 2015

The resent trends show orientation of government's policies towards reduction of the institutional fragmentation of social benefits administration by establishing one-stop-shop social services delivery model. The consolidation of the non-insurance social benefits and in certain cases integration with the unemployment allowances, in a unique specialized payment centre is expected to provide financial and procedural rationality and efficiency, as well 
as a higher degree of citizens' rights protection. The fragmented administration for the same category of beneficiaries or family members, even within the frame of one institution, leads to lower levels of efficiency and effectiveness, due to time loss and increased expenses. Literature has documented several advantages of integrative administrative approaches, directed to cost effectiveness and efficiency through avoiding activities duplicateon and overlapping, identification of gaps, errors and fraught in the system, avoiding complex regulations for inter-agency collaboration, sharing of information knowledge, expertise and resources.

When planning the administrative reforms for social benefits payment system, many of the countries included initiatives for integration with employment policies and activation of the social assistance beneficiaries. Those trends led to organizational changes designed to ensure integrated delivery of services. The integration is realized vertically among different levels of governance (as de-concentrated jurisdiction of the state government offices or devolution of state competencies at regional or local level of selfgovernment) or horizontally (linking services provided by separated entities at the same level of governance). The vertical integration reforms were conducted in Denmark, Germany, Italy and Poland. The countries that undertook activities for horizontal integration are divided in three groups: integration of the unemployment allowances administration (tax-financed and benefits-based: Estonia), integration of the long-term unemployment allowances administration (collaboration between the employment agencies and the municipal administration: Finland, Germany, Ukraine) and integration of all functions for all types of beneficiaries (Austria, Norway) (Scharle, 2014). Several successful attempts of services integration have already been identified in literature, generally in the Nordic countries and Great Britain. Great Britain, for example, concentrates the liabilities for the employment services and social benefits (also regarding unemployment benefits and the social assistance benefits) in one national agency, while there is a historically significant fragmentation of liabilities between the different agencies and government levels in France and the Netherlands (Mosley, 2011).

\section{Trends in organizations of social services delivery}

The guidelines for improvement of the social services provision in the countries from South-East Europe are rooted in several conditions specific for their evolution path (Fultz, Tracy, 2004):

- In the period following the 1990's, the countries were facing a situation where the social protection, to a great extent, relied on large residential institutions to provide care and protection, especially for children, older persons and persons with disability. This organization is in conflict with the protection based on the human rights' principle. Also, residential protection 
is costly, requires large investments, maintenance and staff. As a result, most governments are engaged in efforts to reduce residential care in favour of community-based alternatives.

- The de-institutionalization process is especially present in the countries from the former communist block with weakly developed services network. Moreover, the transition brought new social problems (unemployment, poverty, social exclusion) while casting light on some pre-existing ones (alcohol and drugs addiction, human trafficking). Together, these conditions have caused enormous need for developing a wide range of social services. Many of the countries revised the relevant normative acts and have legally projected wide range of community-based social services.

- The public efforts for developing a comprehensive system of social services are limited by several reasons: lack of resources and trained staff as well as inefficient inter-agency and multi-sectoral cooperation. As a result, the administrative reform initiatives are oriented towards decreasing the state monopole in the social area, and inclusion of the non-state actors in social services delivery. This is drafting a detailed legislation for implementation of social contracting and inclusion of different mechanisms for financing social services delivery.

- The request for quality social services delivered by non-state actors has imposed a need for introduction of a registration procedure and requirements for acquiring a work permit (license). Also, the countries develop standards for providing different types of services, with the purpose to create unified criteria guaranteeing minimum quality.

- Neo-liberal approach to public policy boosted the possibilities for social services purchase on the quasi market (social services marketization) by determined price with clear regulation policies for complete or partial payment release for the beneficiaries with insufficient incomes.

The integration in the European Union, and sharing the mutual values and principles with the old member states led to a certain degree of social policies convergence. Yet, the modalities for adaptation and re-organization of the social services vary between the member states also, thus reflecting certain differences in the national institutional frameworks. Essentially, organizational and managerial reforms of the social services delivery in the member states are driven by four directions, each with the aim for increasing the efficiency and the effectiveness of the social service provision (Social Protection Committee, 2013):

- Performance measurement: Introduction of performance measurement systems, including key performance indicators, and consideration of the information gained as a result of performance measurement in the processes of decision making. 
- Service beneficiary orientation and access to social rights: quality and efficiency improvement, especially by direct information feedback between the beneficiaries and the service providers, increased autonomy of the beneficiaries and strengthened capacity for social inclusion. Various models of beneficiary engagement are developed depending on whether he/she is treated as a citizen enjoying human rights (welfarist approach), consumer with possibility for choice and exit (consumerist approach) or involvement in the processes (participationist approach). In practice, the chosen strategies are generally a mixture of these different models.

- Integration of welfare and health services: from a historical point of view, health and social services are organized by different institutional actors, fragmented in specialized services. Examples for integration of the services in the field of long-term care can be found in Italy (Lombardy), where health care vouchers are used (social and health).

- Decentralization: general tendency in the member states, although, in most of them, a number of social policy instruments remains in the competency of the state authorities. Besides formulation of political goals and adoption of legislation, the state has a regulatory and monitoring authority over most of the national social insurance, social protection and employment institutions.

- Changing the forms of regulation and social networks management: market-oriented regulation (from regulations for public programming towards market regulation).

\section{Conclusion}

The Republic of Macedonia is facing a significant challenge for the reform of the social protection system. The experience of other countries with administrative reforms in this area may serve as a significant resource in developing normative solution and strengthening the institutional capacities for the realization of the social protection activities. The lessons learned from the implemented reforms show that the key factor in the processes of transfer of knowledge and good practices is the adaptation to the local context. Based upon this, countries searching for new institutional solutions for restructuring of the social protection systems should review the examples of reform activities implemented in a socio-political framework similar to theirs.

Basically, three main dimensions, that should be considered in the institutional analysis, are identified: the broader social context in which reform is being implemented (history, tradition, influences, strategic goals), political regulation (political system, organization of the local self-government, degree of centralization/decentralization) and the existing institutional arrangements of the social security system. 
Experiences of the European countries engaged in administrative reform activities of the social protection system can serve as a significant resource for drafting institutional solutions adjustable to the local context:

- Normative regulation of the social protection system in one legal text is not always the best legislative solution, since it creates a complicated legal framework with many general provisions that are hard to follow, especially from beneficiaries' point of view.

- Central governance of the social security system through one ministry enables a holistic approach and connection between the social protection and the social insurance systems. Competencies' division within many ministries often leads to an overlap of authorizations, loss of energy in long and tiring negotiation processes for certain budget solutions, establishment of different agencies, and increased administrative expenses.

- Integration of the non-insurance social benefits administration in one specialized central payment system with deconcentrated regional offices and contact places in the local self-government units.

- Decentralization of services on local level by creating a strong central mechanism for regulation, supervision and financing.

- Drafting clear, simple and transparent rules for social contracting with non-state providers of social services, minimum quality standards, work permit (license), price regulation and participation in payment.

Several key factors have been identified as a pre-condition that determines the reforms' success: clear division of competencies between the central and local government, sustainable sources for social services financing, transparent contract mechanisms and a system for legal monitoring and professional supervision. The quality of the public administration, its capacity to articulate the goals and implement the political solutions may also affect policy outcomes, especially in case of complex institutional reforms. Finally, the institutional changes may be constrained by the historical roots of welfare regimes, which set states on distinct trajectories that tend to be difficult to reverse. Differences in the bureaucratic tradition or the institutional culture of the organizations that should change have also been identified as important barriers of successful institutional reform of the social protection. Such rigidities are likely to affect the transferability and the success of particular institutional arrangements recognized as good practices in other countries. This means that the lessons learned from the experiences of other countries can be applicable only with significant adjustments based on a comprehensive analysis and consideration of the differences in the local context (Scharle, 2014). 


\section{References}

Barnett, S. et al. (2010). Contracting for Quality: ESN research study on the relationships between financer, regulator, planner, case-manager, provider and user in long-term care in Europe, European Social Network.

Commission of the European Communities. (2008). Biennial report on social services of general interest. Brussels, 2.7.2008 sec (2008)2179.

European Community Programme for Employment and Social Solidarity. (2011). Achieving Excellence in Social Service Provision Synthesis Report, Brussels.

Ferrera, M. (1996). The "Southern" Model of Welfare in Social Europe. Journal of European Social Policy 6 (1).

Golinowska, S. et al. (2009). Diversity and Commonality in European Social Policies: The Forging of a European Social Model, ed. Golinowska, S., et al. Friedrich-Ebert-Stiftung and Wydawnictwo Naukowe Scholar.

Greve, B. (2015). Introduction: Europeanization of Welfare, in: Social Policy \& Administration, Regional Issue: Europeanization of Welfare, Volume 49, Issue 4.

Lendvai, N. (2007). Europeanization of social policy? Prospects and challenges for South East Europe. In B. Deacon \& P. Stubbs (Eds.), Social policy and international interventions in South East Europe (pp. 22-44). Cheltenham: Edward Elgar.

Moreno, L. (2006). The Model of Social Protection in Southern Europe. Enduring Characteristics? in: Revue française des affaires sociales 2006/5.

Mosley, H. G. (2011). Decentralisation of Public Employment Services, The European Commission Mutual Learning Programme for Public Employment Services DG Employment, Social Affairs and Inclusion.

Scharle, A. (2014). Literature review and identification of best practices on integrated social service delivery. Luxembourg: Publications Office of the European Union, 2014.

Fultz, E., M. Tracy, M. (2004). Good Practices in Social Services Delivery in South Eastern Europe. Budapest: International Labour Office.

Social Protection Committee. (2013). Policy reforms for growth and cohesion: Review of recent structural reforms, Luxembourg: Publications Office of the European Union.

Social Protection Committee. (2014). Social Europe - Aiming for inclusive growth - Annual report of the on the social situation in the European Union. Luxembourg: Publications Office of the European Union.

Social Protection Committee, 2015, Review of recent social policy reforms, Luxembourg: Publications Office of the European Union. 